\section{On Mere Theistic Evolution}

\author{
Thomas H. McCall \\ in The 71st Annual Meeting of the Evangelical Theological Society
}

https://doi.org/10.54739/mt3a

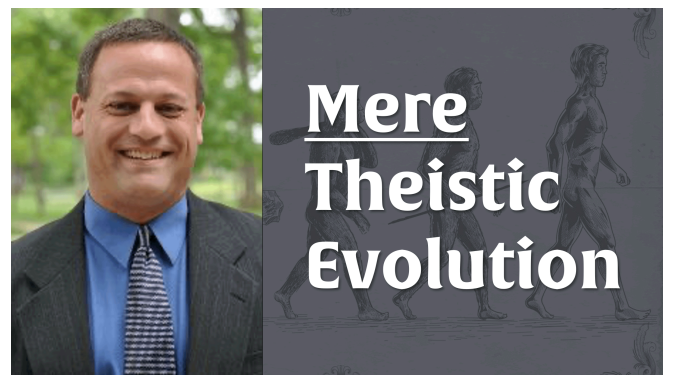

What Michael J. Murray and John Ross Churchill offer as "Mere Theistic Evolution" is an intriguing proposal that should be taken seriously by Christians who are convinced of the truth of classical Christian theology while also engaged in respectful and appreciative dialogue with the natural sciences. In this essay, I argue that the main theological arguments against theistic evolution put forth in the influential volume Theistic Evolution: A Scientific, Philosophical, and Theological Critique are not decisive against mere theistic evolution. The proposal raises many interesting and important issues, and it deserves further engagement.

\section{In Appreciation: Important Apologetic and Pastoral Elements}

This is an important event. It is exactly the kind of conversation that we should be having. I am deeply honored and grateful to be part of it. Seriously. Thank you. What I say here I say as a theologian. I am not a scientist; I am but a mere theologian ... and a pastorally-sensitive and pastorallymotivated theologian at that.

I am struck by how much common ground there is here. In particular, I am thinking of how both "sides" (if we need to talk that way) are motivated by pastoral and apologetic concerns. Both those who produce thousand-page tomes against theistic evolution, and those who are open to theistic evolution or "evolutionary creationism," are driven to articulate and defend their views by a concern to maintain both the intellectual credibility and spiritual vitality of the faith. I know that what I am saying here is pretty basic, but I also think that it is important. So I don't want us to lose sight of this point.

These basic concerns are, of course, driving the authors and editors of Theistic Evolution: A Scientific, Philosophical, and Theological Critique in a rather different direction than the authors of the paper under our consideration. ${ }^{1}$ The authors and editors of TE have different emphases and come to different conclusions on several important issues. I confess that I find myself sympathetic to concerns

This article was first presented in a session of The 71st Annual Meeting of the Evangelical Theological Society. It was then published, closed access, in Philosophia Christi. from both directions. J. P. Moreland, for instance, sounds the alarm about the prevalence and power of scientism in our time. I share that concern. I too worry about the dominance and hegemony of scientism. I am grateful for Moreland's stout resistance; I'm with him on that.

At the same time, within some evangelical Christian circles I see a pronounced distrust of science. This suspicion is not evenly distributed or steady, of course; I don't know too many Christians are resistant to, say, cancer treatments or pacemakers. I do, on the other hand, know many Christians who are happy to appeal to scientific support of some pro-Christian truth claim or even to parade the scientific credentials of well-trained scientists who are Christians. But when it comes to certain fields or areas of study, there is considerable mistrust and suspicion. Moreover, as work by Elaine Ecklund and others has shown, evangelical Christians are underrepresented (and sometimes significantly underrepresented) in some fields in the natural sciences. ${ }^{2}$ To put it plainly, there are a lot of Christians who are physicians and engineers, but not so many leading researchers in biology. This too is discouraging and concerning to me.

So I want to oppose scientism-but also to do all that I can to encourage good science! Indeed, I want Christians not only to engage in science but also to do so while motivated and supported (as well as guided in the proper sense) by theology. But I also want-as I'm sure we all do-to avoid setting up any extra or artificial conflicts. Thus our topic of discussion is of immense importance. We all want to affirm all that is explicitly taught in Scripture or entailed by biblical teaching, and we all want to affirm

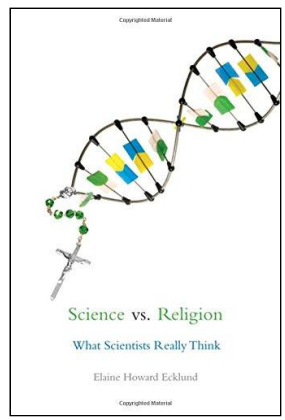
and encourage good science. We want-or at least should want-to avoid unnecessary conflicts. But what does that mean? What do we do with theistic evolution?

It is unfortunate that the possibility of Mere Theistic Evolution (MTE) is not really considered in TE. Consider the definition of theistic evolution offered there:

\footnotetext{
1. Moreland, J. P., Meyer, Stephen C., Shaw, Christopher, Gauger, Ann K., and Grudem, Wayne, eds. Theistic Evolution: A Scientific, Philosophical, and Theological Critique (Wheaton, IL: Crossway, 2017). Subsequent citations are included parenthetically within the text.

2. Ecklund, Elaine. Science vs. Religion: What Scientists Really Think (New York: Oxford University Press, 2010)
} 
(TE) God created matter and after that did not guide or intervene or act directly to cause any empirically detectable change in the natural behavior of matter until all living things had evolved by natural processes (784 and throughout).

As a definition, this is critically ambiguous. It might-might-work as a summative description of the views of some proponents of theistic evolution, but it does not tell us much about theistic evolution more broadly. And it almost certainly does not capture the commitments of MTE. Unfortunately, arguments that purport to overthrow theistic evolution (as defined in TE) may not be so much as relevant to MTE. Even if successful against some expressions of theistic evolution, they can hardly be taken as decisive against MTE. So, again, what are we to make of MTE?

\section{Getting Clearer: The Rationale for MTE}

I think that it is important to get clear-or at least clearer-on the rationale for MTE. The paper under consideration raises this issue and makes some key points, but it seems to me that some of these crucial points are often overlooked and easily misunderstood. So I want to highlight some main points here.

So far as I can see, the MTE proposal is simply a theory that seeks to make sense of two sets of claims drawn from several mines of data. I take it that this kind of theory-production is the sort of thing that we do all the time in both science and theology. Consider any two sets of claims (a) and (b). These (a) and (b) are not completely disparate; we are not talking about "nonoverlapping magisteria." Suppose that both sets of claims seem to enjoy considerable support; both are plausible or probable (or what have you). But ( $a$ ) and (b) seem to be in tension. It is not immediately obvious how to hold with consistency to both (a) and $(b)$, and, when reflecting on the situation, some people are tempted to give up on either $(a)$ and $(b)$. But then someone else comes along and says. "Hey, chill out, here is a way that both (a) and (b) can be true, all we have to do is add in some proposed reconciling theory R." R is supposed to help us make sense of (a) and (b) together. Perhaps R itself is not demanded by the scientific support for either (a) or (b). Well, so what? This does not count against the theory itself.

As the authors of the MTE paper point out, these sorts of moves are made all the time when theologians consider various challenges. So the Bible seems to teach (or presuppose, or imply) both meticulous providence and the reality of human freedom and responsibility. Some theologians and philosophers think that it can't be the case that both are true. It's either meticulous providence or freedom; pick one. Enter Molinism. Molinism is, as our authors remind us, "the name of a sophisticated proposal that aims to unify two sets of commitments: commitment to human free will, on the one hand, and to God's providential control over all the world's events, on the other."3 Molinism's defenders will sometimes argue that their view actually is, minimally, suggested in Scripture (thus 1 Samuel 23 and so forth). But the main point of the theory is to unify the two major sets of claims, both of which seem to be well-supported by biblical teaching. The success of Molinism does not depend on the successful deployment of a proof text. As our authors remind us, the theory does

3. Murray, Michael J. and Churchill, John Ross. "Mere Theistic Evolution" in The 71st Annual Meeting of the Evangelical Theological Society, 2019. https://doi.org/ 10.54739/6qip "not aim to provide any positive evidence for the existence of God or for the reality of human free will," nor does it "aim to explain human agency in any illuminating sense." Thus "to object to Molinism on the grounds that it does neither of these things is to fail to understand its value." ${ }^{4}$ Molinism is just a test case; we could multiply these all over the common topics of theology (for example, the Trinity).

As a layman, it seems to me that this is the kind of thing that sometimes happens in science too. For instance, consider what Darrell Falk does when discussing the evolution of old world and new world monkeys. After noting the proliferation and diversity of new world monkeys (currently 124 species), he compares them with old world monkeys (which tend to have narrower snouts, nostrils that face down rather than up, and very little in the way of tails rather than the long prehensile tails common in South America). ${ }^{5}$ He notes that fossils found from about thirty-five million years ago show close relationships between monkeys of the old and new worlds and lead us to the conclusion that they stem from the same ancestral species. This raises a question: how, then, did they get separated? The easy answer would seem to be that the continents of Africa and South America were formerly contiguous and that the separation of the continents (which had to do with tectonic plate shifts) resulted in the changes that we now see in the various species of monkeys. Alas, this explanation is too easy and will not work. It will not work because the continental shift took place about 100 million years ago, and the strikingly close similarities in the fossil record are about 60-70 million years later than that. So how did they get separated, how did these monkeys get from Africa to South America? Falk tells us that "there is almost unanimous consensus" that something close to the following happened: "a small number (perhaps a single pregnant female) was trapped on a huge tropical tree as it floated down river (possibly in a massive flood) and then, having been transported in an ocean current, the tree with its clinging cargo" made it to South America. ${ }^{6}$

We might call this the "Pregnant Hitchhiking Monkey thesis." Note that Falk presents no scientific evidence-morphological, genetic, or otherwise-for the Pregnant Hitchhiking Monkey thesis; he gives us no evidence that this actually happened. I suspect that he fails to offer evidence because there is no such evidence for the Pregnant Hitchhiking Monkey thesis. Nor is it even easy to see how such evidence could be available. Sans evidence, Falk's postulation is also liable to the charge of what-iffery. To be clear, I am

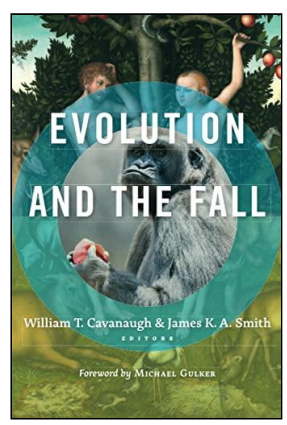
not saying that his claim is in fact false. It surely seems possible, and may indeed be the most plausible suggestion. It looks to me like a possible way of reconciling the belief that these monkeys share common ancestry with the belief that the continents separated tens of millions of years before the changes emerged. So far as I can see, it is no worse off for being the postulate of a possibility. But so far as I can see, that is all that it is. We might wonder why Falk would make such moves. Why does he appeal to a mere possibility to save his

\footnotetext{
4. Ibid

5. Falk, Darrell. "Human Origins: The Evolutionary Story,” in Evolution and the Fall, ed. William T. Cavanaugh and James K. A. Smith (Grand Rapids, MI: Eerdmans, 2017), 18.

6. Falk, “Human Origins," 18-19.
} 
theory? Is not this just a bunch of speculative what-iffery tacked onto interesting scientific findings in order to make some pet theory workable or perhaps even a stubborn, last-ditch effort to salvage a flawed theory? Probably not, or at least not obviously. More charitably, I think that these appeals to possibility most likely are made because the scholars who make such appeals feel evidential pressure from both sides. In other words, they feel the strength of the arguments for both (a) and (b), and they think that it would be a mistake to let the evidence for (a) force them to abandon (b) (or vice versa) unless it could be shown that the propositions are logically inconsistent. I do not fault them for this; I see no problem with the appeals to possibility per se-at least so long as it is admitted that these are mere possibilities rather than presented as if they are part and parcel of the science.

Whatever one makes of the merits of Molinism, it is misguided to reject the theory on the grounds that it does not provide evidence for the existence of God or even of meticulous divine providence. And it would be a mistake to reject it for not offering evidence for human free will (of some libertarian type). Molinism just is not trying to do that. Its success hinges not on its ability to provide such evidence but on its ability to maintain the different affirmations together. Similarly, it wouldn't be right to criticize and reject Falk's theory for failing to provide the right kinds and amounts of morphological and genetic evidence. It simply isn't meant to do that.

Turning back to MTE, it strikes me as both misguided and a bit odd to criticize it for not giving us evidence for the existence of God or for not adding to our knowledge of biology. It simply is trying to make sense of two sets of what might seem to be disparate and even inconsistent sets of claims: on one hand, the important "traditional" theological claims; on the other hand, the evolutionary explanations of the complexity and diversity that we see in biology (15). If it does that well, then it succeeds.

The question is not "but does it make additional scientific claims?" Nor is it "does it give us additional positive reasons to believe in God?" Nor yet is it "Are the views of various prominent proponents of theistic evolution consistent with core Christian doctrines (of a broadly traditional sort)?" In many discussions of these matters-and at many places in the big book - these sorts of questions seem to be conflated and sometimes take precedence. But they are beside the point.

So the big question is: does MTE do its job well? Does it succeed in holding together two sets of claims drawn from different data mines? More precisely, is it able to maintain core Christian doctrines (of a broadly traditional sort) while also accepting the core claims of evolutionary biology? This, to me, is the central question.

There are many issues at stake here, but for present purposes I'll just focus on two important issues in theological anthropology.

\section{Mind-Body Issues and Theistic Evolution}

Murray and Churchill note that J. P. Moreland and Tapio Puolimatka are concerned about what happens to the soul in a theistic evolutionary framework. Perhaps we can offer an admittedly very rough summary of the basic argument as:
1. Evolution entails either physicalism (according to which there is no soul) or an emergentist account of the soul (according to which what is called "the soul" emerges from what is physical);

2. Neither physicalism nor emergentism is consistent with biblically-grounded and philosophically-satisfying theological anthropology;

3. Therefore, evolution is not consistent with biblically-grounded and philosophically-satisfying theological anthropology.

It seems to me that many proponents of theistic evolution reject (2). And thus they argue that nondualist accounts of the human person are more congruent with biblical teaching (as well as more obviously consistent with contemporary neuroscience and more in vogue in contemporary metaphysics). Moreland and others disagree, of course, and the arguments continue apace. Moreland argues that the common appeals to neuroscience are unsuccessful while John Cooper and others argue that a holistic dualism is the best account of biblical teaching. The common battleground is the territory around (2). But Murray and Churchill make a different argument-they say that (1) is mistaken or at least premature and not adequately established. So, as they see things, the argument of the big book is flawed no matter what one thinks of (2).

What are we to make of this? I'll confess my sympathies for some kind of holistic dualism; I am opposed to physicalism (for several reasons), and I am not attracted to emergentism. But it also seems to me that Murray and Churchill are right. It is wrong-or at least very premature-to assume (1). Here again it is important to keep the earlier observations about the rationale for theistic evolution in mind: the fact that many prominent theistic evolutionists happen to accept (1) (and then reject (2)) is not the issue. Indeed, when considering MTE, this fact is irrelevant.

\section{The Quest for the Historical Adam and Eve}

Turning to another issue, let us consider Wayne Grudem's arguments against theistic evolution. Grudem makes a series of bold claims; among these he says that according to theistic evolution, "Adam and Eve were not the first human beings," that they were never sinless, that they were not the first sinners, that human death was not the result of sin, and that God did not act "directly or specially" in the creation of the first humans $(72-3,785)$.

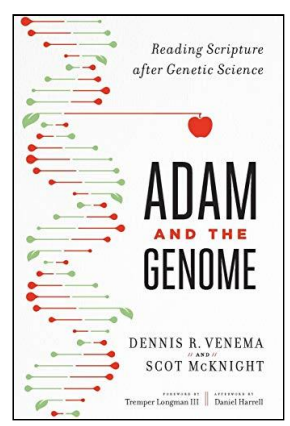

What are we to make of this? It seems to me that Grudem's main argument can be summarized along these lines:

I. Evolution entails conclusions that are inconsistent with any claims that there was an initial human couple from which all other humans descend;

II. Any biblically-faithful theological anthropology will include the affirmation that there was an initial human couple (the "Historical Adam and Eve") from whom all other humans descend, and whose actions adversely affect all humans (the "Doctrine of Original Sin"); 
III. Therefore, evolution entails conclusions that are inconsistent with any biblically-faithful theological anthropology.

Defenders of (I) deploy an impressive array of arguments for their view. For decades, studies in paleontology have produced morphologically-based challenges to notions of a historical first couple. In more recent years, studies in human genetics have provided evidence of an ancestry that is shared in common with other primates as well as evidence that the initial human population would have had to emerge as several thousand breeding pairs. On the basis of such evidence, many theistic evolutionists accept (I) and reject (II). They argue that science demonstrates the "impossibility" of a historical Adam and Eve, and then they often argue that the Bible as properly understood (that is, within its ancient near east, second-temple Judaism, and GrecoRoman contexts) really does not demand a historical Adam and Eve anyway. ${ }^{7}$ As we can see, the argument from (I)-(III) purports to show the incompatibility of evolution and a properly biblical theological anthropology. To avoid the conclusion, many theistic evolutionists accept (I) (often with enthusiasm) and reject (II) (sometimes, alas, with what seems like disdain).

Again, in the interests of transparency, let me say that (II) seems right to me. I am unpersuaded by claims of such Old Testament scholars as John Walton and New Testament scholars such as Scot McKnight on these matters. But neither am I convinced that theological arguments put forward by Grudem are successful, for I do not see that (I) is unassailable. To the contrary, there are multiple ways of contesting the claim made there. I mention two here. The first is what is sometimes referred to rather loosely as

"Refurbishment Proposals." On these proposals, one way to maintain consistency is to accept the standard evolutionary account but then suggest that God took two existing hominins and "refurbished" them. Thus one accepts (or at least can accept) the "orthodox" evolutionary story; one need not quibble with the standard claims about the age of the universe, the development of life on this planet, the emergence of mammals and other primates and then hominins that finally developed into Homo sapiens and then into "modern humans." On this account, prehuman hominins develop physically, mentally, and (presumably) perhaps to some degree spiritually in the long and bloody process basic to the evolutionary model. And then, at the right moment (if not the "fullness of time" then at least the setup for that

7. On “impossibility," see, e.g., Venema, Dennis R. and McKnight, Scot. Adam and the Genome: Reading Scripture after Genetic Science (Grand Rapids, MI: Baker Academic, 2017), 55; Giberson, Karl. Saving the Original Sinner: How Christians Have Used the Bible's First Man to Oppress, Inspire, and Make Sense of the World (Boston: Beacon, 2015), 173; Enns, Peter. The Evolution of Adam: What the Bible Does and Doesn't Say about Human Origins (Grand Rapids, MI: Baker Academic, 2012), 138; Ruse, Michael. "Human Evolution: Some Tough Questions for the Christian," in Human Origins and the Image of God: Essays in Honor of J. Wentzel van Huysteen, ed. Christian Lilley and Daniel J. Pedersen (Grand Rapids, MI: Eerdmans, 2017), 158. "fullness"), God acts to radically change the state, status, and future of a certain species. As the nineteenth century Methodist theologian William Burt Pope puts it, "created out of the dust, he [Adam] is a development of older physical types, a final development on which evolution has spent itself, found worthy at last to be the receptacle of an immortal spirit." 8 God "refurbishes" a pair of these existing creatures; God "elects" them for relationship and service. ${ }^{9}$ These humans-and their progeny-are gifted with the divine image and the mental, relational, and spiritual gifts and responsibilities that come along with that image.

A representative statement of this comes from Peter van Inwagen, and I quote in extenso:

For millions of years, perhaps for thousands of millions of years, God guided the course of evolution so as eventually to produce certain very clever primates, the immediate predecessors of Homo sapiens. At some time in the last few hundred thousand years, the whole population of our pre-human ancestors formed a small breeding community-a few thousand or a few hundred or even a few score. That is to say, there was a time when every ancestor of modern human beings who was then alive was a member of this ... group of primates. In the fullness of time, God took the members of this breeding group and miraculously raised them to rationality. That is, he gave them the gifts of language, abstract thought, and disinterested love-and, of course, the gift of free will. Perhaps we cannot understand all his reasons for giving human beings free will, but here is one important one we can understand: He gave them the gift of free will because free will is necessary for love. God not only raised these primates to rationality-not only made of them what we call human beings-but also took them into a kind of mystical union with himself, the sort of union Christians hope for in heaven and call the Beatific Vision. Being in union with God, these new human beings, these primates who had become human beings at a certain point in their lives, lived together in the harmony of perfect love and also possessed what theologians used to call preternatural powers. Because they lived in the harmony of perfect love, none of them did harm to the others. Because of the preternatural powers, they were able somehow to protect themselves from wild beasts ... from disease ... and from random, destructive natural events (like earthquakes) which they knew about in advance and were able to escape. There was no evil in their world. And it was God's intention that they should never become decrepit with age or die, as their primate forebears had. But ... they abused the gift of free will and separated themselves from their union with God .... ${ }^{10}$

8. Pope, William Burt. A Compendium of Christian Theology: Being Analytical Outlines of a Course of Theological Study, Biblical, Dogmatic, Historical, 2nd ed., 3 vols., (London: Wesleyan Conference Office, 1880), 1:405, cited in Livingstone David N. Darwin's Forgotten Defenders: The Encounter between Evangelical Theology and Evolutionary Thought (Grand Rapids, MI: Eerdmans, 1987), 135-6.

9. Different versions of the Refurbishment Proposal may vary here; some (mind-body dualists) may take this to be or include the "ensoulment" of these hominins, others may associate this directly with the imago dei, etc.

10. van Inwagen, Peter. The Problem of Evil (New York: Oxford University Press, 2006), 84, 86 
From there, we know the rest of the story. The Fall brought sin and suffering, death and destruction. Different variations fly beneath the Refurbishment flag. The version offered by van Inwagen is only one option. Various biblical scholars and theologians have suggested some version or other of this proposal, and indeed there are different views on the market. Denis Alexander, John R. W. Stott, C. S. Lewis, Gavin McGrath, and others have posited something like this. ${ }^{11}$ Recently, James K. A. Smith has offered something along these lines (albeit as a "provisional model as a kind of thought experiment"12). Some people take this "refurbishment" to have happened a very long time ago, while others take it to be much more recent. ${ }^{13}$ Some versions of this proposal would include the bestowal of a "soul;" others (such as van Inwagen's own) might not. A variation might hold that God so refurbished more than the initial couple; on this twist, Adam and Eve are the "top two" (the "chieftains") but not the only two. This variant would, of course, also help to explain how the children of the first couple found spouses (without resorting to sexual relations with other nonhuman but biologically-compatible hominins and thus raising worries about bestiality) and encountered others (as in Genesis 4).

It does not take a lot of reflection to see that van Inwagen's proposal is simply not committed to Grudem's list of objectionable positions. On van Inwagen's view, one can say that Adam and Eve indeed were the first human beings, one can affirm that God indeed acted "directly and specially" to create them, that they were sinless before the fall, and that death came upon them and their descendants as a result of the primal sin. Grudem might object that of course Adam and Eve had parents who were human beings, but to do so he would have to provide a non-question-begging account of what humanity is. And if humanity is defined theologically, or with an essential theological component, then doing so may be an uphill climb for Grudem.

Suppose that someone suspicious of MTE and sympathetic to Grudem's concerns continues to worry that the approach of van Inwagen and other "Refurbishment-ers" does not do enough. Many critics of MTE will remain convinced that a theological proposal that follows the biblical account must have an Adam and Eve who were created de novo. Well, there are options here too. For instance, Joshua Swamidass argues that it is possible that the basic evolutionary story is true and that Adam and Eve were created de novo. ${ }^{14}$ To do so, Swamidass draws an important distinction between genetics and genealogy, and he argues that the first Adam could be the genealogical Adam who is the progenitor of every living human being. If Swamidass is correct, then the presuppositions that are

11. See the discussion in Collins, C. John. Did Adam and Eve Really Exist? Who They Were and Why You Should Care (Wheaton, IL: Crossway, 2011).

12. Smith, James K. A. "What Stands on the Fall? A Philosophical Exploration," in Evolution and the Fall, ed. William T. Cavanaugh and James K. A. Smith (Grand Rapids, MI: Eerdmans, 2017), 61.

13. Denis Alexander's model takes it to be recent; see his Creation or Evolution: Do We Have to Choose? (Oxford: Monarch Books, 2008).

14. Swamidass, S. Joshua. The Genealogical Adam and Eve: The Surprising Science of Universal Ancestry. (Downers Grove, IL: InterVarsity Academic, 2019) common to young-earth creationists and some evolutionary creationists as well as many secular evolutionists are questionable. The details of the theory are becoming well-known and need not detain us here, and it is safe to say that his proposal will be met with considerable interest and close scrutiny. But the basic point should be clear: if Swamidass is right, then we have a defeater for (I). And without (I), of course, there is no reason to think that the major claims of biological evolution are inconsistent with belief in a historical Adam.

Critics both left and right may protest that such proposals as these are not demanded by either Scripture or science. In other words, the details of neither Swamidass's Genealogical Adam proposal nor van Inwagen's Refurbished Adam are produced by good exegesis of the Bible (in either testament). Nor are such details demanded by good science. Recognizing this, critics may charge these proposals-and, more broadly, MTE-of being unacceptably ad hoc. But at this point it is again important to remember the rationale for MTE. Again, MTE is not trying to provide additional positive reasons to hold to traditional Christian belief (or even to theism). Nor is MTE trying to add to our knowledge of biology. No, MTE is only trying to show that it is possible to believe in both traditional Christian doctrine and evolutionary biology. Similarly, neither the Refurbishment proposals or the Genealogical Adam proposal are intended to give us additional positive arguments for a historical Adam (although the Genealogical Adam proposal may offer some scientific support). Nor are they trying to prove that an evolutionary account is true. They are only intended to show that one can hold to both. So if one has good theological reasons to maintain the traditional doctrinal claim, then one should maintain that theological conviction-and can do so without fear of contravening the science. And if one thinks that one has good scientific reasons to accept evolutionary biology, then one can do so without having to jettison the traditional theological belief. The fact-if it is a fact-that one does not have scientific support for the theological claim is irrelevant. So what? Nor is the fact that one does not have theological or biblical support for the scientific claim. Again, so what? If one has good reason to hold to the theological claim of a historical Adam, then one should hold to that. And if one has good reason to accept the conclusions of contemporary science on these matters, then one should do so. The benefit of the two strategies (Refurbishment theories and the Genealogical Adam theory) is to show that it is possible that both the science and the theology are true.

So here are two ways (or, more properly, two families or phyla of ways) forward; here are two ways that someone could maintain MTE and still retain belief in (II). I have no doubt that there are other ways, and I am not arguing that these two are the best ways forward. My point is not that we should adopt either of these or that we should accept the evolutionary account. My point is rather more modest: it is possible that both the important theological convictions and the scientific claims are true. Thus Grudem's conclusion is at best overstated and premature. Indeed, not only is it premature, I find it to be also irresponsible and unhelpful. 


\section{Conclusion}

In hearty agreement with the convictions expressed in $T E$, I am opposed to scientism and quite concerned about the magnitude of its impact. We really do live in a culture where research scientists are seen as the high priests; they know the secrets, they can promise good fortune, and they are qualified to deliver pronouncements about matters far beyond their expertise and far above their pay grade. I too am concerned about this hegemony. More positively, I appreciate very much-and wholeheartedly agree with-the fundamental convictions of the big-book that Holy Scripture is wholly true and finally normative in all of our theory-building. I am finally accountable to how God has revealed himself and his works, and all my theorizing should strive to be informed by, and consistent with, such revealed truth. Amen to all that.

But I am also concerned about the possibility that we might choose the wrong battlegrounds. Indeed, it is my commitment to biblical authority in the face of scientism that motivates this very concern. I do not want to see us tie biblical authority to matters that simply are not issues of biblical authority. If, to revisit the "historical Adam" issue, we are sure that contemporary evolutionary science rules out the possibility of a historical Adam and we are sure that the Bible demands the reality of a historical Adam, then we indeed have a problem: it's one or the other, and Christians committed to the truthfulness and authority of the Bible will go with the right one. But if we are not so sure, then we should not be tying these issues so tightly together. For to do so runs the very real risk of devaluing the truthfulness and trustworthiness of the Bible in the eyes of many people ... people old and young, scientists and clergy, seekers and saints. So: are we so sure? It seems to me that we have not tested the viability of MTE. I cannot see why MTE should not be a live option and worthy of further consideration.

So far as I can see, we are not in a position to conclude that MTE has been weighed in the balances and found wanting. Instead, the arguments in TE really don't weigh it at all (at least not in the theological discussions). There is considerable criticism of John Walton, Peter Enns, Scot McKnight, Karl Giberson, and others, and some of this is helpful. But in many places the arguments are not at all convincing. For instance, the chapter on historical theology seems to equate Isaac la Peyrère's "Pre-Adamitism" with "Refurbishment" views, but these are not the same. (Pre-Adamite theory holds that there were humans before Adam and that Adam was simply the first Jew, but Refurbishment proposals can hold that any hominin ancestors are strictly speaking, prehuman, and thus insist that Adam was the first human (940ff.)). Similarly, the chapter on the Old Testament concludes with a recitation of the Westminster Larger Catechism Q/A17-but without doing anything at all to show that MTE is inconsistent with it (878)! John Currid claims that "Pelagianism is almost an inevitable result of the denial of the historical Adam and Eve" (878n115), and Guy Waters says that semi-Pelagian and Pelagian conclusions "follow directly" from a denial of the historical Adam (915). But they give us no argument for this conclusion, and it is far from obvious that they are correct. In point of fact, some prominent theistic evolutionists are more likely liable to the opposite heresy, for their enthusiasm to affirm original sin leads them close to something more like gnosticism-where sin and suffering are a necessary part of embodied life. As I noted earlier, Grudem's definition of theistic evolution is remarkably rough and simply cannot be considered anywhere close to something that is descriptive of the MTE proposal (784). Overall, MTE really isn't evaluated. But it should be engaged.

Obviously, there is more work to be done. There are many remaining questions about a wide range of issues, and these deserve further reflection. There are further questions about divine providence, about what is often called "natural evil," about human uniqueness and morality and significance and so much more. These need to be taken with utmost seriousness.

In the conclusion of one of his chapters, Moreland says that "the Christian community expects more courage out of its leaders" (658). I couldn't agree more. He also says that "we run the risk of making our own desired views of biblical interpretation more authoritative than the text itself" (658). Again, I couldn't agree more. I would only add that I think that the Christian community sometimes needs to see more humility from its intellectual leaders-and perhaps a little more patience and a bit less pressure to crank out surefire answers to really hard questions on very complex issues.

\section{References}

Moreland, J. P., Meyer, Stephen C., Shaw, Christopher, Gauger, Ann K., and Grudem, Wayne, eds. Theistic Evolution: A Scientific, Philosophical, and Theological Critique. (Wheaton, IL: Crossway, 2017)

Ecklund, Elaine. Science vs. Religion: What Scientists Really Think. (New York: Oxford University Press, 2010)

Murray, Michael J. and Churchill, John Ross. "Mere Theistic Evolution” in The 71st Annual Meeting of the Evangelical Theological Society, 2019. https://doi.org/10.54739/6qip

Falk, Darrell. "Human Origins: The Evolutionary Story," in Evolution and the Fall, ed. William T. Cavanaugh and James K. A. Smith (Grand Rapids, MI: Eerdmans, 2017)

Venema, Dennis R. and McKnight, Scot. Adam and the Genome: Reading Scripture after Genetic Science. (Grand Rapids, MI: Baker Academic, 2017)

Giberson, Karl. Saving the Original Sinner: How Christians Have Used the Bible's First Man to Oppress, Inspire, and Make Sense of the World. (Boston: Beacon, 2015)
Enns, Peter. The Evolution of Adam: What the Bible Does and Doesn't Say about Human Origins. (Grand Rapids, MI: Baker Academic, 2012)

Ruse, Michael. "Human Evolution: Some Tough Questions for the Christian," in Human Origins and the Image of God: Essays in Honor of J. Wentzel van Huysteen, ed. Christian Lilley and Daniel J. Pedersen (Grand Rapids, MI: Eerdmans, 2017)

Pope, William Burt. A Compendium of Christian Theology: Being Analytical Outlines of a Course of Theological Study, Biblical, Dogmatic, Historical, 2nd ed., 3 vols. (London: Wesleyan Conference Office, 1880), 1:405

Livingstone, David N. Darwin's Forgotten Defenders: The Encounter between Evangelical Theology and Evolutionary Thought. (Grand Rapids, MI: Eerdmans, 1987), 135-6.

van Inwagen, Peter. The Problem of Evil. (New York: Oxford University Press, 2006)

Collins, C. John. Did Adam and Eve Really Exist? Who They Were and Why You Should Care. (Wheaton, IL: Crossway, 2011) 
Smith, James K. A. "What Stands on the Fall? A Philosophical Exploration," in Evolution and the Fall, ed. William T. Cavanaugh and James K. A. Smith (Grand Rapids, MI: Eerdmans, 2017)

Alexander, Denis. Creation or Evolution: Do We Have to Choose?. (Oxford: Monarch Books, 2008)
Swamidass, S. Joshua. The Genealogical Adam and Eve: The Surprising Science of Universal Ancestry. (Downers Grove, IL: InterVarsity Academic, 2019) 